Third World Politics 


\title{
Third World Politics
}

\author{
A Comparative Introduction
}

Second Edition

Paul Cammack, David Pool and William Tordoff 
(C) Paul Cammack, David Pool and William Tordoff 1988, 1993

All rights reserved. No reproduction, copy or transmission of this publication may be made without written permission.

No paragraph of this publication may be reproduced, copied or transmitted save with written permission or in accordance with the provisions of the Copyright, Designs and Patents Act 1988, or under the terms of any licence permitting limited copying issued by the Copyright Licensing Agency, 90 Tottenham Court Road, London W1P 9HE.

Any person who does any unauthorised act in relation to this publication may be liable to criminal prosecution and civil claims for damages.

First edition 1988

Reprinted 1989, 1990, 1991, 1992

Second edition 1993

Published by

\section{THE MACMILLAN PRESS LTD}

Houndmills, Basingstoke, Hampshire RG21 2XS

and London

Companies and representatives

throughout the world

ISBN 978-0-333-59467-4 hardcover

ISBN 978-0-333-59468-1 paperback

A catalogue record for this book is available

from the British Library.

Copy-edited and typeset by Povey-Edmondson

Okehampton and Rochdale, England

ISBN 978-0-333-59468-1

ISBN 978-1-349-22956-7 (eBook)

DOI 10.1007/978-1-349-22956-7 
To Anamaria and Daniela Cammack, Hannah, Thomas and Lydia Pool, and the memory of Dora Tordoff 


\section{Contents}

List of Maps viii

Changes in Country Names ix

Preface xi

Introduction 1

1. The Heritage of the Past 15

2. State and Society 56

3. Political Parties and Participation 94

4. The Military 133

5. Revolution 170

6. Women in Third World Politics 209

7. The International Context 248

8. The Third World in the Global Economy 286

Bibliography 323

Index $\quad 339$ 


\section{List of Maps}

1 Africa 19

2 East and Southeast Asia 27

3 Latin America 35

4 The Middle East 43 


\section{Changes in Country Names}

Throughout the text, the name by which the country was known at the date relevant to the discussion is used. Changes of name usually occurred at independence; post-independence changes are indicated in brackets.

Present

Benin (1975)

Botswana

Burkina Faso (1984)

Burundi

Cameroon

Cape Verde

Central African Republic

Congo

Côte D'Ivoire

Djibouti

Equatorial Guinea

Ghana

Guinea-Bissau

Lesotho

Malawi

Malaysia (1963) ${ }^{6}$

Mali $^{7}$

Myanmar (1989)

Namibia

Rwanda

Saharan Arab

Democratic Republic ${ }^{8}$
Pre-independence

Dahomey

Bechuanaland

Upper Volta

Ruanda-Urundi ${ }^{1}$

$\{$ French Cameroons

British Southern Cameroons ${ }^{2}$

Cape Verde Islands

Oubangui Chari

French Congo ${ }^{3}$

Ivory Coast ${ }^{4}$

French Territory of the

Afars and Issas ${ }^{5}$

Spanish Guinea

Gold Coast and British Togoland

Portuguese Guinea

Basutoland

Nyasaland

Malaya

French Soudan

Burma

South West Africa

Ruanda-Urundi

Spanish Sahara|Western Sahara 
Somalia $\mid$ Somali

Democratic Republic

Tanzania (1965) ${ }^{9}$

Thailand (1939)

Togo

Zaire (1971)

Zambia

Zimbabwe $\left\{\begin{array}{l}\text { British Somiland } \\ \text { Italian Somaliland }\end{array}\right.$

$\{$ Tanganyika

Zanzibar

Siam

French Togoland

Belgian Congo ${ }^{10}$

Northern Rhodesia

Southern Rhodesia $\backslash$ Rhodesia

Notes:

1. Ruanda-Urundi was a Belgian-administered UN trust territory which became independent in 1960 as two separate states.

2. The Southern Cameroons, a British-administered UN trust territory, joined the Republic of Cameroon following a plebiscite in 1961; the people of the Northern Cameroons opted for integration with Nigeria.

3. Often referred to as Congo-Brazzaville.

4. In 1986 the Ivorian government instructed international organisations to use the French language designation in all official documents.

5. Often referred to as French Somaliland.

6. Malaysia was created in 1963, when Singapore and two Britishcontrolled territories in Northern Borneo - Sabah and Sarawak - joined Malaya in a federation. Singapore subsequently withdrew (in 1965) to become an independent city-state.

7. The Mali federation was formed by Senegal and Soudan in 1959, but survived for less than three months after being granted political independence by France in June 1960. France then recognised the separate independence of Senegal and Soudan, and the Union Soudanaise changed the name of Soudan to the Republic of Mali.

8. Or the Sahrawi Arab Democratic Republic. Its international status is disputed by Morocco, which claims the territory.

9. The United Republic of Tanganyika and Zanzibar came into being on 26 April 1964, as a consequence of the union between Tanganyika and Zanzibar; the name 'United Republic of Tanzania' was officially adopted a year later.

10. Often referred to as Congo-Léopoldville and subsequently (from 1 July 1966) as Congo-Kinshasa. 


\section{Preface}

This is a revised and extended second edition of the text first published in 1988. Firstly, sections on East and Southeast Asia have been added to those already covering Africa, Latin America and the Middle East. For the most part, these new sections centre on four selected case studies, chosen to limit the amount of background historical material required, and to maximise our ability to address important comparative themes: South Korea, Taiwan, Indonesia and the Philippines. Where particular themes justify our doing so, we have ventured outside this set of four cases. We include this new material, with apologies for our lack of regional expertise, in the conviction that the comparative scope of the text is thereby strengthened. Secondly, we have expanded the introductions and conclusions to each chapter, to allow a fuller discussion of the comparative themes advanced. Thirdly, we have converted all footnotes to Harvard references within the text, provided considerably extended suggestions for further reading for each chapter, and listed all the works to which we refer in a single bibliography. We feel that these changes have considerably enhanced the teaching value of the text as a self-sufficient introduction to Third World Politics. In conjunction with the sources discussed in the Further Reading sections, it provides a suitable basis for a semester-long or year-long introductory course. We hope that it will also prove valuable both for teachers of comparative politics who have previously concentrated primarily on the United States and Western Europe, and wish to add a broader comparative dimension, and for area specialists, familiar with some but not all of the regions we discuss, who may weight their teaching towards one or two particular areas, but welcome the potential for broader comparison.

As in the previous edition, Paul Cammack is responsible for the sections on Latin America, David Pool for those on the Middle East, and William Tordoff for those on Africa. For this second 
edition, Paul Cammack was responsible for the final editing, and wrote all the sections on East and Southeast Asia with the exceptions of Chapters Four (William Tordoff) and Five (David Pool).

We thank our publisher, Steven Kennedy, for his encouragement, and Ray Bush, Diane Elson, Barry Munslow, Georgina Waylen, Ralph Young and anonymous readers for their extremely helpful comments and suggestions. The final responsibility, as always, is ours.

Paul Cammack David Pool William Tordoff 